\title{
Commentary \\ Recently published papers: A series of negative results
}

\section{Robert Galloway and Richard Venn}

\author{
Department of Critical Care, Worthing Hospital, Worthing, West Sussex, BN11 2DH, UK
}

Corresponding author: Robert Galloway, drrobgalloway@gmail.com

Published: 19 February 2009

This article is online at http://ccforum.com/content/13/1/119

(c) 2009 BioMed Central Ltd
Critical Care 2009, 13:119 (doi:10.1186/cc7708)

universal application of intensive insulin therapy to ICU patients'.

The study was powered for an absolute reduction of $8 \%$ based on extrapolating the results from van de Berghe and colleagues' study [1], which showed an absolute mortality reduction of $3.4 \%$. Therefore, it may be criticised that this was an underpowered study; the trend was to a reduction in mortality - a non-significant absolute risk reduction of $3.6 \%$.

To look for a small absolute reduction of mortality a large trial is needed. Currently, such a randomized, multicentered trial is being conducted. Aptly named NICE-SUGAR [5], it completed the last of the recruitment in November 2008 and results are now awaited.

More evidence that tight glucose control may not be beneficial for all patients came from a paper by Oddo and colleagues [6]. They performed a retrospective analysis of data from 20 patients with severe brain injury. As part of an observational study, these patients received intensive insulin therapy to try and keep their systemic glucose levels between 4.4 and $6.7 \mathrm{mmol} / \mathrm{L}$.

Brain tissue markers of glucose metabolism were obtained by a frontal lobe microdialysis catheter. Cerebral glucose levels were measured as were lactate and pyruvate levels. A brain energy crisis was defined as a cerebral microdialysis glucose of $<0.7 \mathrm{mmol} / \mathrm{l}$ with a lactate/pyruvate ratio $>40$.

Systemic blood samples were categorised as low sugar ( $<4.4 \mathrm{mmol} / \mathrm{L})$, tight $(4.4$ to $6.7 \mathrm{mmol} / \mathrm{L})$, intermediate (6.8 to $10.0 \mathrm{mmol} / \mathrm{L})$ and high $(>10 \mathrm{mmol} / \mathrm{L})$. Compared to intermediate control, tight glycaemia control was associated with a greater prevalence of low cerebral microdialysis glucose levels and more brain energy crises. The number of brain energy crises was also associated with an increased risk of hospital death.

$\mathrm{ICU}=$ intensive care unit. 
Although this is only a small study - it too leaves us with difficult questions. It is well accepted that hyperglycaemia should be controlled after head injury - but clearly we need to be careful because tight control may cause harm.

\section{Cardiac arrest management}

Meanwhile, the search for improvement in survival from out of hospital cardiac arrest continues. Approximately $70 \%$ of patients with cardiac arrest have underlying acute myocardial infarction or pulmonary embolism. Therefore, there could be a role for routine use of thrombolysis during CPR.

A pan-European study [7] investigated this. Patients who had a presumed cardiac related cardiac arrest were randomised in the pre-hospital setting to either tenecteplase or placebo. If the patient was in asystole or PEA (pulseless electrical activity), the drug was given immediately. If in a shockable rhythm, then it was given after the third shock if there had been no return of spontaneous circulation. The primary end point was 30 day survival. Unfortunately, the results showed no improvement in survival or in any of the secondary outcomes. Although this study shows that there is no evidence for routine use of thrombolysis in cardiac arrest, the authors make it clear that the results do not suggest that thrombolysis should be withheld in patients in whom the primary pathological condition is known to be responsive. Indeed, patients who were presumed to have a pulmonary embolus were excluded from the randomisation and given tenecteplase.

\section{Nutrition on ICU}

There is evidence that providing early nutritional support to ICU patients reduces mortality. However, this is not universally followed. Doig and colleagues [8] presented a clustered randomised controlled trial across 27 ICUs in Australia and New Zealand to see if evidence-based feeding guidelines could be implemented and reduce mortality. Half the participating ICUs carried on their normal feeding policy whilst the other half implemented evidence-based guidelines with specific measures aimed at improving compliance with the guidelines. A practice-change strategy of 18 specific interventions was devised. Individual hospitals used various aspects of this strategy.

The results of the study show that although guideline ICUs fed patients earlier and achieved calorific goals more often, there was no significant difference in mortality, ICU length of stay or hospital length of stay. This surprising and somewhat disappointing result needs explanation. It could be that original research from which the guidelines were taken either overestimated the benefit of early feeding or was not transferable to this patient setting.

Other explanations may be that compliance with the guidelines was not $100 \%$ or the 'Hawthorne' effect of the control group. Knowing that they were being studied may have led to improvements in their nutrition management regardless of guidelines. But the important take home message is that implementing nutrition clinical care guidelines improves feeding regimes.

\section{Rapid response teams}

Although it seems rational to have outreach teams that respond to a set of deranged physiological parameters, few studies have showed evidence for their benefit and others show no benefit [9]. Another negative trial is from Kansas, Missouri [10]. A prospective cohort study looked at over 24,000 adult inpatients admitted for 20 months before and after a rapid response team was introduced. The general trends in the first 20 months (that is, the decreasing number of cardiac arrest calls) were taken into consideration in the statistical analysis.

Although there was a reduction in the number of out of ICU cardiac arrests, this did not translate into a significant difference in hospital mortality. It may be that introducing a rapid response team allows a more dignified death in those whose resuscitation is futile and, therefore, reduces the number of cardiac arrest calls without improving mortality. On the other hand, mortality may not have been affected because the interventions were ineffective. This needs further study.

\section{Competing interests}

The authors declare that they have no competing interests.

\section{References}

1. Arabi YM, Dabbagh OC, Tamim HM, Al-Shimemeri AA, Memish ZA, Haddad SH, Syed SJ, Giridhar HR, Rishu AH, Al-Daker MO, Kahoul SH, Britts RJ, Sakkijha MH: Intensive versus conventional insulin therapy: a randomized controlled trial in medical and surgical critically ill patients. Crit Care Med 2008, 36: 3190-3197.

2. van den Berghe G, Wouters P, Weekers F, Verwaest C, Bruyninckx F, Schetz M, Vlasselaers D, Ferdinande $P$, Lauwers $P$, BouilIon R: Intensive insulin therapy in the critically ill patients. $N$ Engl J Med 2001, 345:1359-1367.

3. Van den Berghe G, Wilmer A, Hermans G, Meersseman W, Wouters PJ, Milants I, Van Wijngaerden E, Bobbaers H, Bouillon $\mathrm{R}$ : Intensive insulin therapy in the medical ICU. $N$ Engl J Med 2006, 354:449-461.

4. Brunkhorst FM, Engel C, Bloos F, Meier-Hellmann A, Ragaller M, Weiler N, Moerer O, Gruendling M, Oppert M, Grond S, Olthoff D, Jaschinski U, John S, Rossaint R, Welte T, Schaefer M, Kern P, Kuhnt E, Kiehntopf M, Hartog C, Natanson C, Loeffler M, Reinhart K; German Competence Network Sepsis (SepNet): Intensive insulin therapy and pentastarch resuscitation in severe sepsis. N Engl J Med 2008, 358:125-139

5. Normoglycaemia in Intensive Care Evaluation and Survival Using Glucose Algorithm Regulation (NICE - SUGAR STUDY) [http://clinicaltrials.gov/ct/gui/show/NCT00220987]

6. Oddo M, Schmidt JM, Carrera E, Badjatia N, Connolly ES, Presciutti M, Ostapkovich ND, Levine JM, Le Roux P, Mayer SA: Impact of tight glycemic control on cerebral glucose metabolism after severe brain injury: A microdialysis study. Crit Care Med 2008, 36:3233-3238

7. Böttiger BW, Arntz HR, Chamberlain DA, Bluhmki E, Belmans A, Danays T, Carli PA, Adgey JA, Bode C, Wenzel V; TROICA Trial Investigators; European Resuscitation Council Study Group: Thrombolysis during resuscitation for out of hospital cardiac arrest. N Engl J Med 2008, 359:2651-2662.

8. Doig GS, Simpson F, Finfer S, Delaney A, Davies AR, Mitchell I, Dobb G; Nutrition Guidelines Investigators of the ANZICS Clinical 
Trials Group: Effect of evidence-based feeding guidelines on mortality of critically ill adults: a cluster randomized controlled trial. JAMA 2008, 300:2731-2741.

9. Hillman K, Chen J, Cretikos M, Bellomo R, Brown D, Doig G, Finfer S, Flabouris A; MERIT study investigators: Introduction of the medical emergency team (MET) system; a cluster randomised controlled trial. Lancet 2005, 365:2091-2097. Erratum in Lancet 2005, 366:1164.

10. Chan PS, Khalid A, Longmore LS, Berg RA, Kosiborod M, Spertus $J A$, Hospital-wide code rates and mortality before and after implementation of a rapid response team. JAMA 2008, 300: 2506-2513. 